\title{
Causes and Consequences of the Expansion of Soybean in Argentina
}

\author{
S. Calvo ${ }^{1}$, M. L. Salvador ${ }^{1}$, S. Giancola ${ }^{2}$, G. Iturrioz ${ }^{2}$ \\ M. Covacevich ${ }^{2}$ and , D. Iglesias 2 \\ ${ }^{1}$ National University of Córdoba \\ ${ }^{2}$ National Institute of Agricultural Technology -INTA \\ Argentina
}

\section{Introduction}

Soybean production in Argentina started in the seventies "as a productive option to provide proteins for animal feeding. This was fostered by the National Institute of Agricultural Technology (INTA) at a national level and by the Argentine Institute for the Oilseeds Development (IADO), currently closed" (ACSOJA, 2009). In spite of this, the soybean development was very slow until the mid 90s, when two technological milestones occurred: no-till farming and the inclusion of transgenic seeds.

The development of this chain is shown in its growing competitive power. Indeed, Argentina has kept and increased its presence in the world market, being the third exporting country of soybean ( $13 \%$ of the total exports). It is also the first world exporting country of soybean oil and meal (55\% and $50 \%$ share of the total exported). Finally, the export goods of the soybean chain represent the first exportation item of the Argentine economy (2010/2011).

This may be explained by four factors: a) the agro ecologic suitability, b) the constant improvement and technological innovation, c) the most modern and of major scope crushing facilities for soybean of the world, d) the high exportable surplus due to low domestic consumption.

In the last ten years, the development of this chain not only has favored the members of the chain -producers, manufacturers, exporters, merchants- but also the National State, which by means of the implementation of export duties ${ }^{1}$ obtains strong revenues.

In spite of the favorable setting in which the soybean chain appears both, at a national and international level, this crop is questioned by several agents who analize how the soybean spreading is shifting the agricultural frontier. This expansion in turn is causing the substitution of agricultural and stockbreeding products, the use of not suitable lands for agriculture, the extinction of small-size producers and environmental damage among other consequences.

Therefore, the goal of this work is to describe and analize the evolution of the soybean chain in Argentina through indicators and explicative factors ${ }^{2}$ referred to the primary, industrial

${ }^{1}$ Up to March 2010, they amount to 35\% for grain and 32\% for soybean oil and meal. 
and exporta sectors, since the mid seventies up to the present time, with special emphasis on the last thirty years. The aim is to outline the probable future context that the direct and indirect agents connected to the soybean complex will face.

\section{Primary production}

At the beginning of the seventies, the soybean cultivated area reached 30,470 hectares with a total output of 26,800 tons. The low importance of this crop may be explained by the lack of attractive markets, the low international prices and the national trade policy, which strongly restricted the exportation of grain and byproducts (Civitaresi and Granato, 2003).

The expansion of the cultivated area and yields started during the seventies. The cultivated area increased $6,792 \%$ between the $1969 / 1970$ and the 1979/1980 seasons and $143 \%$ between 1979/1980 and 1989/1990 whereas the production increased 12,959\% and $206 \%$ considering the same periods. Likewise, the soybean yields increased $32.7 \%$ between $1970 / 1971(1,024 \mathrm{~kg} /$ hectare) and 1989/1990 (2,157 kg/ha). This outstanding growth was due, among other endogenous causes, to technological changes and its fast adoption shown in the improvement of agronomic management, agricultural mechanization and agrochemicals application (Civitaresi and Granato, 2003). In addition, the double crop wheat-soybean ${ }^{3}$ began to develop.

Among the exogenous causes that explain the growth in this twenty years (1970/1990), highlights the increase of international prices in the mid seventies, reduction of export duties, elimination of exportation ban (1978) and modification of the policy carried out by the European Economic Community (EEC) nowadays European Union (EU). In the 70s, the EEC negotiated the entry of soybean and its byproducts with zero tariff according to a restructural procedure of its Common Agricultural Policy in the framework of the Dillon Round of the General Agreement Tariff and Trade (GATT) (1960/1961). The strong expansion of its milk production and the subsequent need to feed its cattle urged the strong demand of vegetable proteins. The EEC tried -unsuccessfully- to cover its needs with its own cereal production by restricting the access to imported cereals (as the wheat bran from Argentina), but it could not restrict the entry of soybean, which was protected by the commercial concession in the framework of the GATT4 (Albin and Paz, 2003).

In the last twenty years, the process of expansion of the soybean cultivated area has continued uninterrupted. The cultivated area increased $72.3 \%$ between 1989/1990 and $1999 / 00$ and $108.7 \%$ between 1999/00 and the last season 2009/2010. In addition, the soybean production increased $88.2 \%$ and $162 \%$ for the same periods.

In Figure 1 it can be seen the expansion of the cultivated area and of the soybean production $^{5}$ as well as the leap in both indicators since the year 1996.

2 It will be applied the definition by Civitaresi and Granato (2003) which classifies the factors into exogenous: that depend on macro economic policies and on international commerce, and endogenous: that derive from the strategies carried out by the protagonists of the different links of the chain.

3 The short cycle wheat allows the sowing of wheat-soybean in the same agricultural cycle and in the same area

4 In the eighties, it tried to "under strengthen" the soybean and its derivatives: this situation led to serious confrontations with the U.S.A.

5 The decrease in production in 2008 and part of 2009 was due mainly to a drought and partly to the conflict between the agricultural sector and the Government. The conflict was originated by the implementation of "mobile export duties" by the Economy Minister (the duties varied according to the 


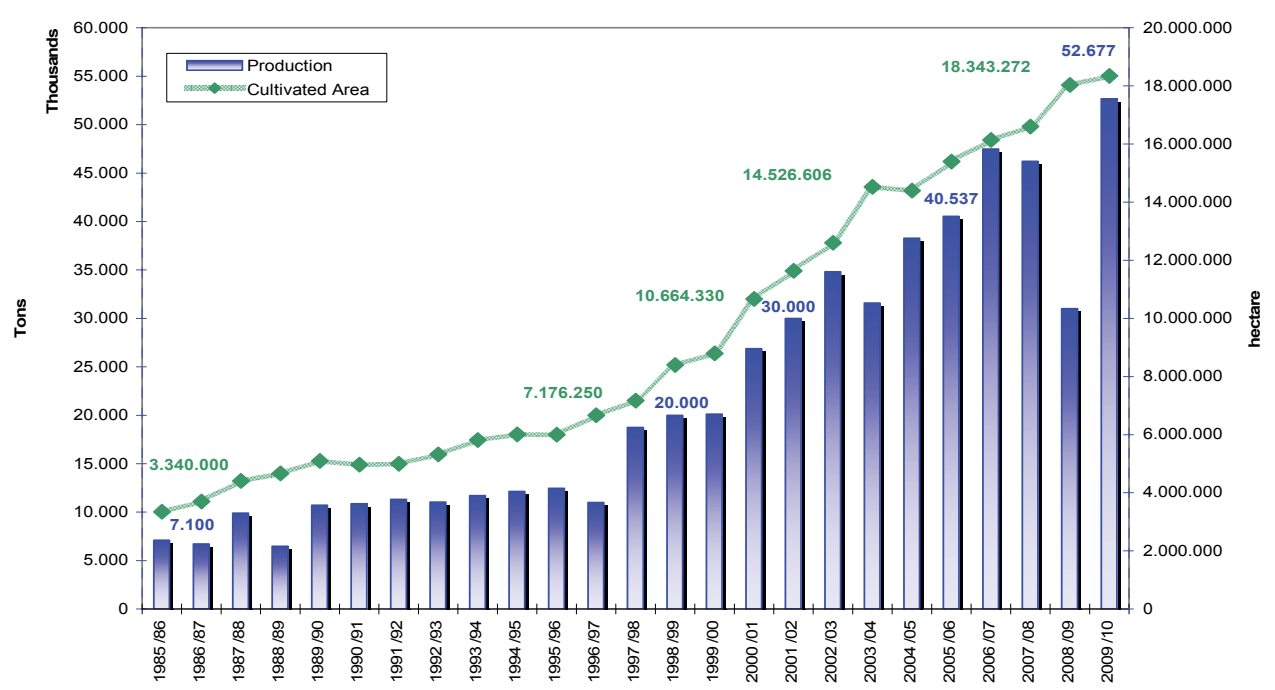

Fig. 1. Argentina soybean. Production and Cultivated Area. Years 1885/86 to 2009/2010.

Specifically in the nineties, the following endogenous factors can be featured as causes of the expansion: the genetic modification in several crops -among them the events in the soybean seed and consequently the start of the transgenic technology spreading at an international level-, and the intensification in the use of machinery and supplies, mainly the "glyphosate" 6 herbicide. In addition, a fundamental change in the plowing system took place: no-till cropping, which deserves a special paragraph.

"No-till cropping started to gain importance in the Argentine agriculture in the late eighties since in many of the most important areas of the Pampeana region, the cumulative effects of the soil erosion -resulting from the "agricultural cultural process" on the basis of traditional plowing practices- began to show negative operative results in the exploitation. This effect on yields, and through them, on the economic feasibility of agriculture, together with the fact that, as a result from the deregulation and opening processes of the economy, the availability of appropriate farming machinery increased, plus the reduction in direct costs (as a result of the elimination of the plowing tasks), provided an outstanding basis for the spreading of no-till cropping, which in turn had the objective of recovering, at least some of the lost productivity" (Trigo and Cap, 2006).

Fuethermore, the synergy between glyphosate tolerant soybean tolerant (RR-soybean) and the non-till system -which shortens the required time between the wheat harvest and the soybean planting- makes possible the successful use of short cycle soybean varieties as second crop and allows a double-cropping wheat-soybeans in zones where before was not possible from an agronomic point of view. According to data provided by the Argentine No Till Farmers Association (AAPRESID), at the beginning of the nineties, the area of soybean

variations in the international price of the soybean). This duties were enforced from March 2008 to July 2008 (they were derogated by a legislative decision).

${ }^{6}$ In the 2009/2010 season, more than 200 millon liters of glyphosate were applied in all the soybean sown area in Argentina, whereas in 199613 million liters were used 
under no-till cropping system reached $6 \%$, whereas in the $2001 / 02$ season it was $74 \%$, in $2006 / 07$ it accounted to $85 \%$ and in $2009 / 10$ it reached $88 \%$.

Analyzing the exogenous factors that fostered the development of soybean in the nineties, highlights the changes in the economic policy: tariff reduction for machinery and inputs imports, reduction and/or elimination of export duties for products of the soybean chain, investments in ports, deregulation of markets (elimination of Meat and Grain Boards) and privatizations (ports, railways) which lessen the cost of production and favor the acquisition of technology.

At an international level, relevant facts such as average international prices lower than in the previous decade, the increase of commercial barriers in the rest of the world (in spite of the final Agreement of the GATT's Uruguay Round) have not been auspicious for the soybean chain. In this respect, the only favorable fact was the increase in the demand of grain by the Brazilian oil industry, in the frame of the MERCOSUR (Civitaresi and Granato, 2003).

Going through the last decade, the increase in the soybean cultivated area ${ }^{7}$ is due both to the incorporation of new lands and to the substitution of other crops. The agricultural expansion towards the north of Argentina 8 is shown by a $70 \%$ increase of the cultivated area between the last two National Agricultural Census (CNA 1988 and CNA 20029), although this is a marginal area for this crop. $66 \%$ of the lands transferred to agriculture in the north of Argentina was occupied by soybean (Giancola et al., 2010).

According to Shvarzer and Tavosnanska (2007), the increase in the production for the last ten years might have several causes. One of them is the increase in international prices because of the growing world demand for soyean oil and meal. Another cause is the technological change, which involved a reduction of related costs. Likewise, between the years 2000 and 2010 it is worth mentioning: the intensification of the technological package, scale incrementes in the productive core, the suitability of the soil, the existing road infrastructure and the increase of the rainfall (Giancola et al., 2010).

Complementing the previous considerations, among other fundamental causes of the soybean expansion is worth mentioning: higher financial income, lower complexity in the operation and lower risk than other crops, and farmers' knowhow, together with the use of their own seed (INTA, 2009).

As related to the topic of seeds and specially about the use of the varieties of genetically modified soybean ${ }^{10}(\mathrm{GM})$, the data provided by ARGENBIO (a non governmental organization created to spread information about biotechnology) shows that in the $1996 / 1997$ season, the area occupied with GM soybean was $6 \%$ and quickly reached $94 \%$ in $2001 / 2002$ to cover $98 \%$ in $2004 / 2005$.

\footnotetext{
${ }^{7}$ At present (2009/10 season) soybean occupies $18,343,272$ hectares with a production of 52,677,371 tons (CIARA, 2011).

${ }^{8}$ The traditional region for the production of soybean is called "pampeana" and it is made up by the provinces of Córdoba, Buenos Aires, Santa Fe, Entre Ríos and La Pampa.

${ }_{9}^{9}$ At a primary level, $75 \%$ of the production comes from $40 \%$ of the productive units (100,000 units). The average size of the units is 170 hectares.

${ }^{10}$ The gene resistant to the glyphosate herbicide was initially owned by Monsanto in the United States, which granted a license to Asgrow, then this company was bought by Nidera, which introduced it in Argentina. Afterwards, when Monsanto patented the product abroad, it had already been freed by third parties to be sold in Argentina (Quaim and Traxler, 2002). This situation started a controversy between Monsanto and the Argentine government, in which the company has claimed in order to obtain royalties.
} 
Even in Argentina, these adoption was faster than others, as for example hybrid corn or wheat with Mexican germplasma. Hybrid corn lasted 18 years to reach $70 \%$ of the acceptance that nowadays GM corn holds, and Mexican wheat reached the same percentages of adoption as soybean has nowadays (more than $90 \%$ of the market) only after 16 years (López, 2006, as cited in Trigo and Cap, 2006).

Another factor that favored the technological change is related to inputs supply for the soybean crop (Bisang, 2003) which has the following characteristics: a) technological packages: the transgenic seed -RR Soybean- works as a connector of a joint supply that includes: glyphosate, pre-emerging herbicides, insecticides and fertilizers; b) mergers and alliances with companies that offer such technological packages ${ }^{11}$; c) the packages of supplies offered in service centers include advice about usage techniques.

Finally, soybean share of total cultivated area and grain production of the country allows to visualize the strong soybean expansion in Argentina (Figure 2). According to production data, soybean represented $0.2 \%$ of the total cultivated area12 (14 million hectares) in the $1969 / 1970$ season. In the seventies, the soybean cultivated area occupied $3.1 \%$ of the total sown, in the eighties 19\%, in the nineties 33\% and in the first ten years of the 21st century soybean occupied $54 \%$ (more than 18 million hectares) of the total (28 million hectares) implanted.

Regarding the importance of soybean production, and considering the total produced by the five main grains, the participation of soybean was $3.7 \%$ on total production in the seventies, $18 \%$ in the eighties, $30 \%$ in the nineties and $50 \%$ in the first ten years of the 21 st century (CIARA, 2011). In the 2009/2010 season, the soybean production represented $60 \%$ of the total production whereas it was $0.12 \%$ in the $1969 / 70$ season.

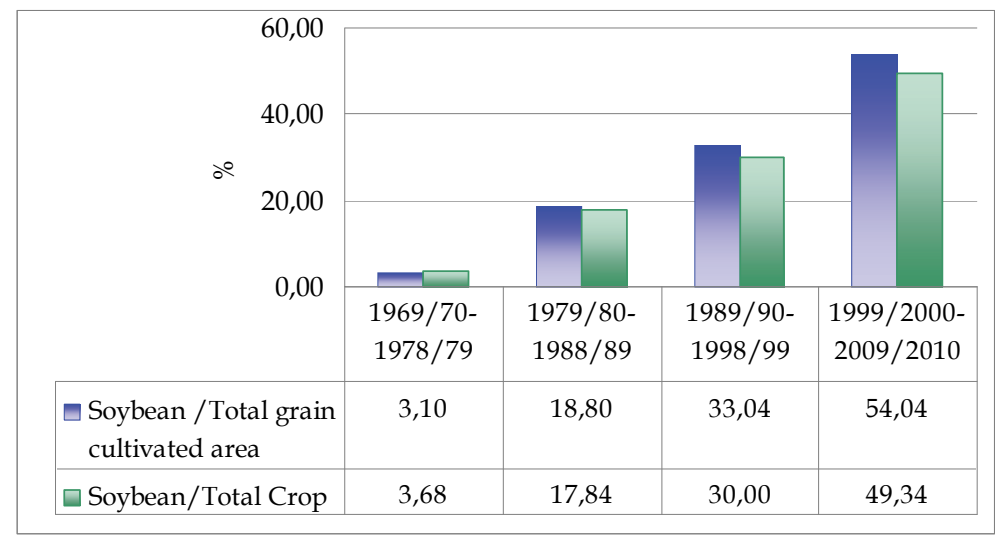

Fig. 2. Argentina. Soybean. Production share of the total produced by the five crops and soybean cultivated area shares of total cultivated area. Periods: 1969/70 - 1978/79, 1979/80 - 1979/80 - 1988/89, 1989/90 - 1998/99 and 1999/2000 - 2009/10.

\footnotetext{
${ }^{11}$ Monsanto (an company originally dedicated to chemistry, which in the70s expanded to pharmaceutical chemistry) is associated with Dekalb and Cargill; the use of these seeds (specially RR Soybean from Monsanto) requires the application of glyphosate, offered by the same company with the brand "Roundup".

${ }^{12}$ Taking into account the five main crops: wheat, corn, sunflower, sorghum, soybean.
} 
With respect to the geographical location, the soybean cultivated area is situated in 15 (fifteen) productive provinces. However, $85 \%$ of the cultivated area is concentrated on the traditional "pampeanas" provinces that generates $88 \%$ of the national production (Córdoba, Buenos Aires and Santa Fe provide $78 \%$ of the total production) whereas $15 \%$ of the remaining area corresponds to Northwester and Northeaster provinces. Map 1 shows the shift of the agricultural frontier ${ }^{13}$.

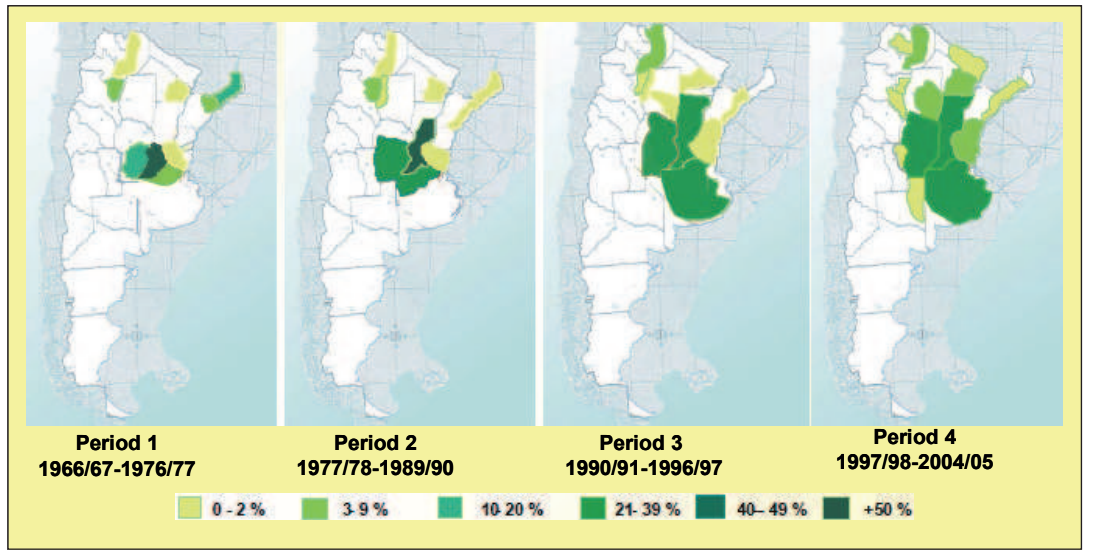

Map 1. Evolution of the space distribution of the soybean cultivated area (Brieva, 2006).

Considering the yields, Figure 3 shows that they have increased continuously, from 1.4 tons/ha in the seventies, to 2.6 tons/ ha in the first decade of 2000.

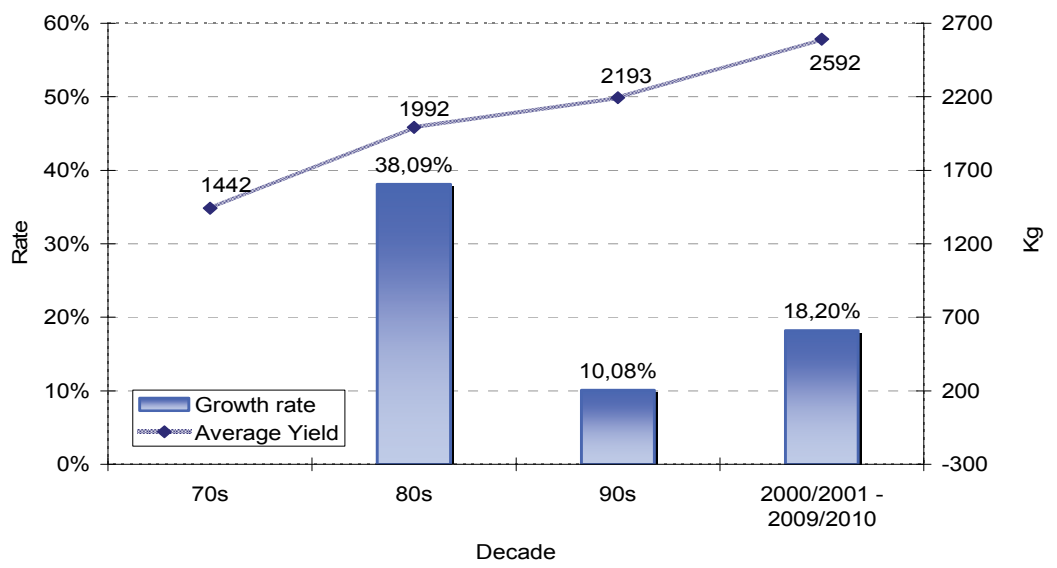

Fig. 3. Argentina Soybean. Average Yields (kg/hectare) and growth rate (\%). 70, 80, 90 decades and 2000/01 - 2009/10 period.

${ }^{13}$ As mentioned, the shift of the agricultural frontier has generated the substitution of crops (sorghums, corn, cotton among others) and cattle livestock for soybean as well as the spreading of soybean over the native forest. 


\section{Industry and state policies}

In the stage of first industrialization or milling, the productions of raw oil and meal are technologically associated, and therefore they are produced in the same industrial plants. Most part of the grain production in Argentina is oriented to milling, with a percentage that varies from $76 \%$ to $80 \%$ of the total production; approximately $18 \%$ of soybean beans is exported without processing and the rest is used for direct consumption, as seeds for sowing or for other purposes (bread, cookies, snacks, peanut butter, bird food, etc).

The industrialization process begins with the milling and extraction of oil. After going through drying - to remove humidity - and cleaning processes, the grain is broken and pressed in small sheets, which being transformed into a dough, move on to the extraction process. The remaining dough, after being dried and toasted, forms the protein meal used in the manufacture of animal feed. The gum can be used in the production of soybean lecithin or can be added to the meal in order to obtain different of protein tenors. Through a hydrogenation process, the partially refined oil can be transformed into margarine, mayonnaise and vegetable fats. Some companies integrate vertically these industrial stages. As other grains with a low oil component, soybean oil is extracted with hexane. The solvent -a petroleum product- impregnated with oil is then separated by evaporation, and goes through a gum elimination system (degummed) to reach the stage of raw oil (Giancola et al., 2010). A soybean yields $19 \%$ oil, $73 \%$ meal, $7 \%$ shell and $1 \%$ others (ashes, etc.), these values may vary depending on the drying and de-shelling degrees ${ }^{14}$.

The manufactured products ${ }^{15}$ are distinguished in two segments: commodities (for exportation and domestic market), which include raw and refined oil in bulk and meal for animals, and speciallities of higher added value for the final consumption of food and other uses. Some companies are present in both segments. The refined oil, apart from its direct consumption (pure or in blends) has several uses, such as margarine, mayonnaise, non edible intermediate products (candles, cosmetics, soap, paint and fine chemicals, animal food, soybean lecithin), hydrogenated vegetable fats (used in cookies, bread, ice-cream, etc), soybean derivatives for human consumption (Gutman and Lavarello, 2003). Regarding non edible uses and oriented to the chemical industry, oil and vegetable fats have similar characteristics to the petroleum ones and can be used for plastics, adhesives, solvents, lubricants, etc.

Another derived product is biodiesel. Compared to other traditional hydrocarbons, biodiesel has several advantages: it comes from a renewable product and has little environmental impact, but it also has disadvantages, being its high cost the main limitation. Biodiesel installed capacity of production is to 2.43 million tons - reaching 3 million tons by the year 2011. In 2010, 1.9 million biodiesel tons were refined and almost 1.4 tons were exported. The 500,000 remaining tons were used in the domestic market for the diesel cut.

In April 2006, Act 26093 established the rules for the regulation and promotion ${ }^{16}$ for Production and Sustainable Use of Bio Fuels for a period of 15 years. This Law establishes that the gasoline and diesel commercialized within Argentina shall be mixed in an oil

\footnotetext{
144 tons of flour are obtained from each ton of oil.

15 The industrial processing generates byproducts that have more restricted but dynamic markets, many of which are not developed enough in Argentina.

16 The Law gives encouragement for investment through fiscal incentives.
} 
distillery or refinery with $5 \%$ - as minimum - of bio ethanol and biodiesel, respectively from $01 / 01 / 2010$ on. For the year 2010, the quantity of biodiesel necessary for the $5 \% 17$ cut was calculated in 625,000 tons, which imply 650,000 tons of oil.

Likewise, the biodiesel industry that is developing in Argentina has a strong orientation towards the foreign market ${ }^{18}$. In Argentina, there are major incentives for the biodiesel exportation as a result of the way in which export duties of the soybean complex are structured. In this respect, the biodiesel exportation must pay $20 \%$ of export duties whereas soybean oil (its main supply) and soybean pay $32 \%$ and $35 \%$ respectively 19 . Thus, there is a gain of competitiveness for biodiesel that comes from the efficiency in the previous links of the chain. In addition, biodiesel obtains a reimbursement of $2.5 \%$ upon the export price, with which the competitiveness reached by the export duties structure is reinforced.

Finally, it is worth mentioning that it is currently spreading the building of small extruding facilities in farms that produce soybean. This allows to obtain oil for its use as biodiesel and protein meal for cattle feeding, adding value to thier soybean production through horizontal and vertical integration

\subsection{Milling capacity}

Milling is the most important destination of the primary production of soybean. While in the eigthies $71 \%$ of the grain production was assigned to milling, in the 90 decade this percentage increased to $77 \%$ and reached $84 \%$ in the first 2000 decade. In the 2008 and 2009 periods, there was a $20 \%$ fall in industrialization (30 million tons average) which can be explained mainly by the decrease in the grain production due to reasons pointed earlier. In the year 2010, the milling reached 34 million tons, similar values to those of the year 2007. This volume represented $98 \%$ of the soybean supply.

In the last years, the crushing capacity grew basically in the province of Santa Fe (at an average rate of $14.4 \%$ ) while in the provinces of Buenos Aires, Córdoba and Entre Ríos it remained practically constant (CIARA, 2011). In the year 2010, soybean crushing in Argentina reached $36,824,628$ tons, which implies $92 \%$ of the total milling of the country $\left(39,898,017\right.$ tons $^{20}$. In 1986 , the soybean milling share of the total milling was $50 \%$. (CIARA, 2011).

The increasing crushing capacity in Argentina is also reflected in the world market. In the last two decades, the world milling has grown at an annual rate of $4.5 \%$. In the same way, the soybean world production is destined mainly to milling (98\%) reaching 200 million tons (2009/2010)(USDA, 2010). The main countries processing soybean are also the main grain producers: U.S.A. Brazil, Argentina, China. Currently, this latter country - which specially has the goal to increase the soybean added value - contributes $21 \%$ of the world milling. This is the reason of the strong grain importation from overseas.

\footnotetext{
17 The national government established that the cut shall be $7 \%$ since 2011.

${ }^{18}$ Nine plants have been authorized to export (2008), 5 of which come from investments made in the oil sector, the rest come from non agro-industrial sectors. The main refineries are: Renova, Louis Dreyfus, Unitec Bio, Patagonia Bioenergía, Ecofuel, Cargill and Aceitera General Deheza. CARBIO (Argentine Chamber of Biofuels, 2011).

${ }^{19}$ The export duties of grain and byproducts had been applied in previous times, as in the eighties (15\% and $41 \%$ for grain) and nineties (3.5\% for grain).

${ }^{20}$ The crushing capacity in Argentina amounts to more than 57 million tons. (2010)
} 


\subsection{Oil and meal production}

Soybean oil production reached 41 million tons, being the main producing countries: China, (10,3 million tons), U.S.A, Brazil and Argentina. Argentina produces 7,3 million tons (2009) and participates approximately with $18 \%$ of the world production.

Argentina has 54 oil producing plants which are distributed in 8 provinces. Thirty-nine of these plants process soybean bean with a theoretic capacity of 160,000tons in 24 hours (CIARA, 2011). Fifty-six percent of the plants that concentrate $84 \%$ of the processing theoretic processing capacity, operate in areas close to shipment centers in the Province of Santa Fe, since the production is oriented to exportation. The processing plants are supplied with soybean within a radius smaller than $300 \mathrm{~km}$, which results in low freight cost. This closeness between primary production and transforming industry generates a major competitive advantage.

Analyzing Table 1, we can see that whereas in the 70 decade, the soybean oil production participated in $8.5 \%$ of total elaborated oil of the country, in the $2000 / 2004$ period this participation increased to $71.88 \%$. In 2009, soybean oil participation in Argentina reached $5,771,812$ tons, thus participating $79 \%$ of the total elaborated oil (7,302,493 tons). Considering the geographical location, the province of Santa Fe elaborated more than $90 \%(2008 / 09)$ of soybean oil total production.

\begin{tabular}{||l|l|l|l||}
\hline & Total Oil (T) & Soybean Oil (T) & Soybean/total (\%) \\
\hline Decade Averages & & & \\
\hline $1970-79$ & 661.517 & 56.118 & 8,48 \\
\hline $1980-89$ & 1.735 .284 & 571.359 & 32,93 \\
\hline $1990-99$ & 3.722 .981 & 1.789 .712 & 48,07 \\
\hline Quinquennial averages & & & \\
\hline $1985-89$ & 2.239 .749 & 842.542 & 37,62 \\
\hline $1990-94$ & 2.951 .163 & 1.360 .297 & 46,09 \\
\hline $1995-99$ & 4.494 .799 & 2.219 .126 & 49,37 \\
\hline $2000-04$ & 5.444 .255 & 3.913 .555 & 71,88 \\
\hline
\end{tabular}

Table 1. Argentina. Total Oil and Soybean Oil Production (tons). Soybean Participation (\%) in the Oil Total. Periods Selected.

The development of the Argentine oil industry was parallel to the growth of the soybean primary production. According to Obschatko (1997) and Civitaresi and Granato (2003) the main factors were: the increase ${ }^{21}$ in the international prices of oil and meal, impelled by the increase in the world consumption and the fluent grain supply (raw material) -at an international level-, and the reduction of taxes for the exports of oil and the application of a lien differential for grain and oil -at national level. The latter measure was fundamental for the development of the industry, according to Obschatko (1997)- in order to prevent the industry from having problems for raw material supply, the National State

\footnotetext{
${ }^{21}$ In the nineties, international prices decreased due to the lower demand by Asian countries and higher presence of other substitute oils. All this took place in a context of strong market distortions due to protectionism mostly inin developed countries.
} 
implemented an effective differential exchange rate for grain, oil and byproducts. Between 1976 and 1990, the differential of export duties between grain and milling products (highly praised) varied between 5.9 and $13.6 \%$. This measure favored the exportation of oil and meal by reducing the cost of the raw material with respect to the international market prices.

At an industrial level, the investment made in this sector as regards technology was complemented with the availability of technology from developed countries- that is the case of the Dutch enterprise (De Smet), which introduced in Argentina the technology of oil extraction by solvent. Likewise, the companies of the industrial link increased the production scale: they specialized in soybean and sunflower; they re-located in the province of Santa Fe -thus combining the closeness to the exportation ports (Rosario) and the sources of raw material supply. Finally, industry integrated forwards by building dock 22 and storage facilities. This process was intensified in the nineties. At a National State level, the tax pressure on the marketing sectors was reduced, the services related to trading activity were deregulated, public ports were privatized and new ports were built. In addition, there were investments for the sweeping and beaconing of the Paraná and Río de la Plata fluvial corridor $^{23}$ (Civitaresi and Granato, 2003).

Soybean processing is concentrated in six companies: Bunge, Cargill, Vicentín, Molinos Río de la Plata, Dreyfus, Aceitera General Deheza, which control more than $87 \%$ of the total capacity. These companies have a modern and efficient port infrastructure of their own and an extended supply net spread throughout the entire country ${ }^{24}$. The oilseeds industry employ 10,000 people. In Table 2, it is identified the number of plants that each of the companies owns as well as the annual processing capacity.

\begin{tabular}{||l|l|l|l|l||}
\hline \hline \multirow{2}{*}{ Company } & Number of & \multicolumn{2}{|l|}{ Total capacity } & Largest capacity \\
\cline { 3 - 4 } & Facilities & Ton/year & $\%$ & Facility (ton/year) \\
\hline Bunge & 5 & 8.220 .000 & 17.8 & 2.550 .000 \\
\hline Cargill & 4 & 7.710 .000 & 16.7 & 3.900 .000 \\
\hline Vicentín & 3 & 6.555 .000 & 14.2 & 3.000 .000 \\
\hline Molinos Río de la Plata & 3 & 6.195 .000 & 13.4 & 3.600 .000 \\
\hline Dreyfus & 2 & 6.000 .000 & 13 & 3.600 .000 \\
\hline Aceitera Gral. Deheza & 4 & 5.700 .000 & 12.3 & 2.550 .000 \\
\hline Buyati & 2 & 1.440 .000 & 3.1 & 1.005 .000 \\
\hline Nidera & 2 & 1.260 .000 & 2.7 & 660.000 \\
\hline OMHSA & 2 & 705.000 & 1.5 & 405.000 \\
\hline Others & 20 & 2.467 .500 & 5.3 & \\
\hline Total & 47 & 46.252 .500 & 100 & 3.900 .000 \\
\hline
\end{tabular}

Source: Schvarzer and Tavosnasnka (2007)

Table 2. Argentina. Oil Factories by Company.

22 In 1977, private companies were allowed to set up fluvial ports.

${ }^{23}$ This corridor is fundamental for the transportation of the grain production from Córdoba and Santa $\mathrm{Fe}$, first and second producing provinces of soybeans.

${ }^{24}$ As regards the production of refined oil, 5 companies have $80 \%$ of the production, 4 companies have $80 \%$ of the margarine production and three companies have $80 \%$ of the mayonnaise production. 
At a world level, and according to USDA data, the production of soybean meal was approximately 177 million tons (2009/10), being the main producers: China, $(25.7 \%$ of the total produced), U.S.A., Argentina (17\% of the world production) and Brazil. These four countries concentrate $78 \%$ of total production (USDA, 2010).

The soybean meal share of total manufactured meal in Argentina has been higher than oil. Thus, whereas soybean meal was $20.87 \%$ of the total output in the seventies, this percentage reached $91.1 \%$ in the 2000/04 period (Table 3). In 2009, the soybean meal production was approximately 23 million tons from a total of 25,520,000 tons of manufactured meal. As in the case of oil Santa Fe province produces $93 \%$ of total soybean meal (2009).

\begin{tabular}{|l|l|l|l||}
\hline Period & $\begin{array}{l}\text { Total meal } \\
\text { production }\end{array}$ & $\begin{array}{l}\text { Soybean meal } \\
\text { production }\end{array}$ & $\begin{array}{l}\% \text { soybean/ } \\
\text { total meal }\end{array}$ \\
\hline Decade average & & & \\
\hline $1970-79$ & 1.268 .956 & 264.807 & 20,87 \\
\hline $1980-89$ & 4.224 .577 & 2.665 .821 & 63,10 \\
\hline $1990-99$ & 10.383 .969 & 8.124 .909 & 78,24 \\
\hline Quinquennial average & & & \\
\hline $1985-89$ & 5.674 .917 & 3.916 .431 & 69,01 \\
\hline $1990-94$ & 8.248 .517 & 6.327 .119 & 76,71 \\
\hline $1995-99$ & 12.519 .422 & 9.922 .700 & 79,26 \\
\hline $2000-04$ & 18.202 .340 & 16.584 .419 & 91,11 \\
\hline \hline
\end{tabular}

Source: CIARA (2010)

Table 3. Argentina. Total Output of meal (tons) and of soybean meal and Participation (\%) in the Total Output of meal. Periods selected.

\section{International trade}

Regarding soybean complex, Argentina exports mainly processed products: protein meal for animal feeding and oil for human consumption. Soybean exportation began its expansion due to the demand from China, which intensified its process of importation substitution (oil).

\subsection{Soybean}

The world production of soybean in the 2010/2011 season reached 255.5 million tons according to USDA. The main producing countries, U.S.A. (35\%), Brazil (26\%) and Argentina (20\%), participate in $82 \%$ of the world production. They are followed by China, with a participation of $6 \%$ although its presence in the world market has the role of importer because of its high domestic consumption.

For a long period of time soybean main demand came from the EU. Since 1998/99, China has incremented its demand for domestic processing and since the 2004/05 harvest China turned into the main world importer of the grain (60\%) followed by the EU $(14.6 \%)$.

As related world suppliers, U.S.A, Brazil and Argentina concentrate $89 \%$ of the total exported (98 million tons) (2009/2010). Argentina occupies the third place as soybean 
exporter in the world with $14,11 \%$ of the total 25 (see Figure 6). Taking into account the six main soybean exporting countries (U.S.A, Brazil, Argentina, Paraguay, China, Canada, Bolivia), three of them - Brazil, Argentina and Paraguay - which make up the MERCOSURrepresent half of the world exportations. This points out the importance of South America in the soybean bean production and exportation.

As seen in Figure 4, the soybean exportation has had a positive trend fostered by the increasing international prices. This indicator -grain exports-26 shows the higher competitiveness of Argentina in the international market.

The main demand of Argentine soybean comes from China. Thus, $78 \%$ of the exported grain had that destination. Argentina also exports to Iran, Thailand and Egypt, and in South America to Chile and Peru.

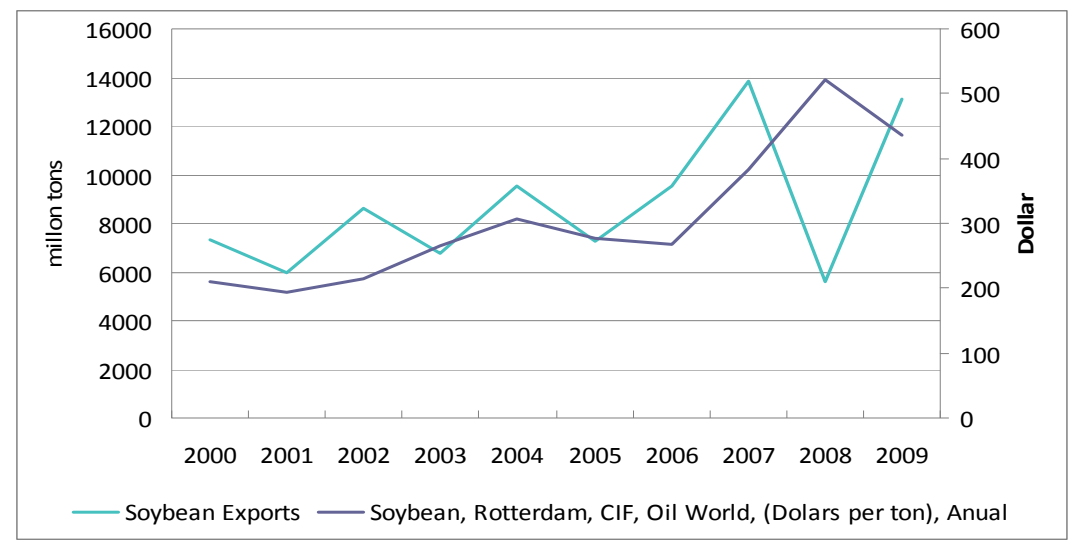

Fig. 4. Soybean. Argentine exportation (million tons) and price (U\$S/ton) (CIF, Rotterdam) $2000 / 2009$.

Argentina has also imported soybean, especially from Paraguay (98 \%) (Figure 5). The need to import soybean can be explained since the processing capacity of the oil industry surpasses the local production of soybean and other oilseeds available for industrialization.

The strong increase in soybean importations since 2006 can be explained by the Decree $2147 / 06$, which was the result of a wide negotiation between the industrial-exporting sector and the national government. This decree allows transitory importation of goods that will be subject to a process of industrial improvement. Decree 2147/06 incorporates a tax benefit upon the imported supply which allowed the exporting companies to pay export duties omly on the added value of the imported bean. Since April 2009, the Argentine Production Ministry excluded 27 the soybean from the tax benefits of temporary importations. This regulation was based on the grounds that it would promote the increase of the soybean demand in the domestic market and diminish the stock of grain stored by producers in their own farms. (Giancola et al., 2010).

\footnotetext{
${ }^{25}$ U.S.A participates with $44 \%$ and Brazil with $32 \%$ of the total world exported of soybean.

26 The decrease in the grain exportation is related to the drop in the production due to a drought (2008 and part of 2009).

${ }^{27}$ That is why no importations have been made since 2009 up to the present.
} 


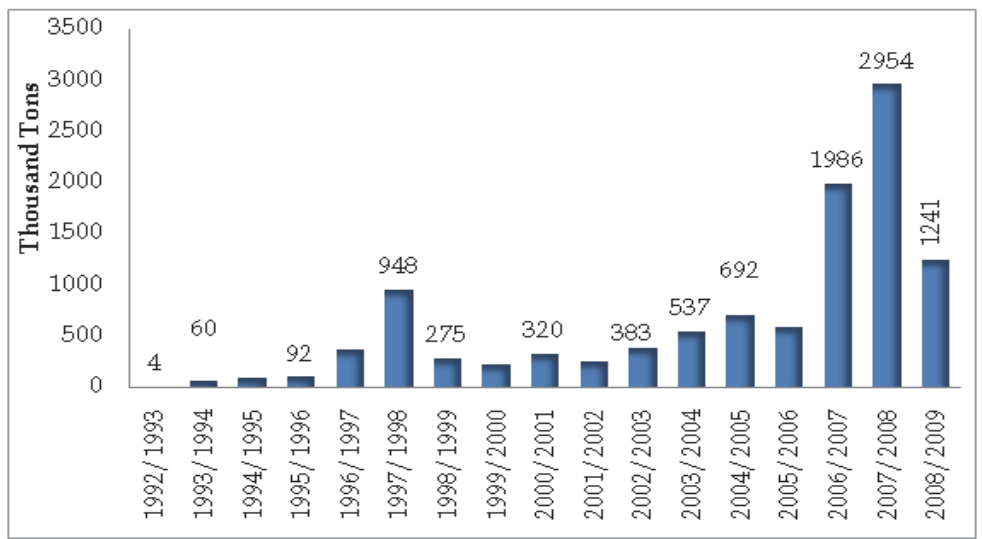

Source: USDA PSD ,2010

Fig. 5. Argentina. Importation of Soybean Bean (tons). 1992/93 - 2008/2009.

\subsection{Soybean oil}

The soybean oil exportation is concentrated in few countries whereas the importation is diversed. So, the first five importing countries (China, India, UE-27, Iran, Morocco) have $52 \%$ of the total imports (2010-2011).

Argentina is the main oil exporting country ${ }^{28}$. With $49 \%$ to $56 \%$ of the world total oil exports, followed by Brazil (16\%) and the United States (13\%). Considering Paraguay, the MERCOSUR is regarded as the main exporting soybean oil block. $96 \%$ of the oil exported by Argentina is raw and degummed. The refined oil incidence is very low.

The following table (4) shows Argentine apparent consumption. The data show that most of the oil production is destined to the exports.

In Figure 6 it is shown the Argentina share of total world soybean oil exported. Its main participation was in the 2005-2006 season $(57 \%)$. Then, this participation decreased until it reached $49 \%$ of the 2009/2010 season. According to USDA estimates, in 2010/2011 season the Argentine exports would reach historical values (54.6\%).

\begin{tabular}{|c|c|c|c|c|c|c||}
\hline Year & 2004 & 2005 & 2006 & 2007 & 2008 & 2009 \\
\hline Inicial stock & 242.326 & 134.024 & 239.000 & 217.578 & 302.083 & 303.968 \\
\hline Production & 4.569 .718 & 5.395 .724 & 6.161 .214 & 6.962 .675 & 6.024 .101 & 5.771 .812 \\
\hline Availability & 4.812 .044 & 5.529 .718 & 6.400 .214 & 7.180 .253 & 6.326 .184 & 6.075 .780 \\
\hline Exports & 4.588 .120 & 4.964 .180 & 6.086 .290 & 6.637 .770 & 5.125 .480 & 4.660 .400 \\
\hline Final stock & 134.024 & 239.000 & 217.578 & 302.083 & 303.968 & 287.668 \\
\hline $\begin{array}{c}\text { Apparent } \\
\text { consumption }\end{array}$ & 89.900 & 326.538 & 96.346 & 240.400 & 896.736 & 1.127 .712 \\
\hline
\end{tabular}

Table 4. Argentina. Apparent consumption of soybean oil.

${ }^{28}$ It is important to point out that since 2007, Argentine began to export biodiesel obtained from soybean. 
Asian countries concentrate most of the Argentine oil demand due to the importance of their growing economy and to the fact that these countries had consumption levels per capita lower than the world average. China $(45 \%)^{29}$, India (14\%), Bangladesh (6\%), Egypt (5\%), Peru (5\%) are the most relevant destinations of the exported oil by Argentina (2010). Seventy eigh percent of the oil imports and $22 \%$ of the soybean imports of China have their origin in Argentina. This shows the strategic importance of soybean and its byproducts in the commercial relationship between China and Argentina.

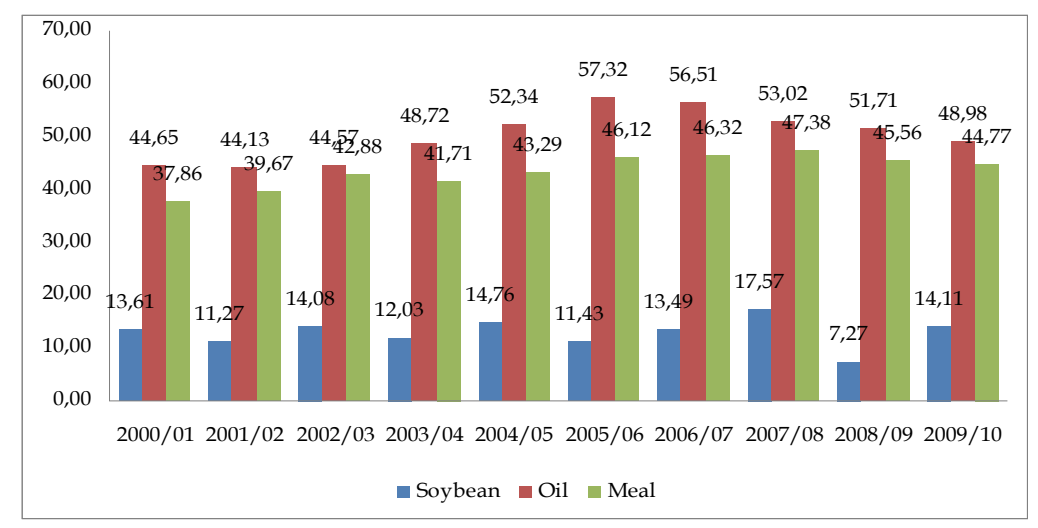

Fig. 6. Soybean. Argentina share of the world grain, oil and meal exports. (\%) 2000/012009/10.

Finally, after a study of the soybean oil exports per company (Table 5) it comes out that the soybean exports market structure is an oligopoly ${ }^{30}$, with foreign capital predomination (transnational companies) (Eumercopol, 2007).

\begin{tabular}{||l|l|l|l||}
\hline Company & $\begin{array}{l}\text { Soybean oil share of } \\
\text { total oil exported (\%) }\end{array}$ & Company & $\begin{array}{l}\text { Soybean oil share of } \\
\text { total oil exported (\%) }\end{array}$ \\
\hline Cargill & 28,42 & Nidera Arg. & 3,12 \\
\hline Bunge Argentina & 18,15 & Aceitera C.A. & 2,65 \\
\hline Aceitera Gral. Deheza & 14,80 & Oleag. Moreno & 1,44 \\
\hline Dreyfus & 10,91 & $\begin{array}{l}\text { Cia. Argentina } \\
\text { de Granos }\end{array}$ & 1,39 \\
\hline Mol. Río de la Plata & 10,36 & A.F.A. & 1,22 \\
\hline Vicentin & 3,31 & &
\end{tabular}

Source: CIARA (2011)

Table 5. Soybean Argentina. Soybean oil exporting companies. Total export share 2008.

\footnotetext{
${ }^{29}$ Due to the commercial restrictions imposed by China to the Argentine oil, the exports were drifted to the markets in India, Bangladesh and Iran at a lower price.

${ }^{30}$ The exports participation of the first eight companies (C 8 ) is: $81 \%$ for grain, $87 \%$ for oil and $97 \%$.for soybean meal.
} 


\subsection{Soybean meal}

As in oil, Argentina is the main exporting country with 29 million tons over an exporting total of 59.4 million (Figure 7). Thus, Argentina keps -in a stable way- $44--46 \%$ (see Figure 6) of the total meal exports, followed by Brazil (23\%) and the United States (14\%). According to USDA for 2010/11 season, Argentina share in soybean meal export would reach $49.3 \%$.

Argentina exports almost all its soybean meal production (between 93\% and 97\%), mainly to the UE-27 countries for animal feeding. The European problem with bovine spongiform encephalopathy, known as the "mad cow disease", put an end to the cattle feeding with animal proteins and intensified the demand of substitute products like the soybean meal.

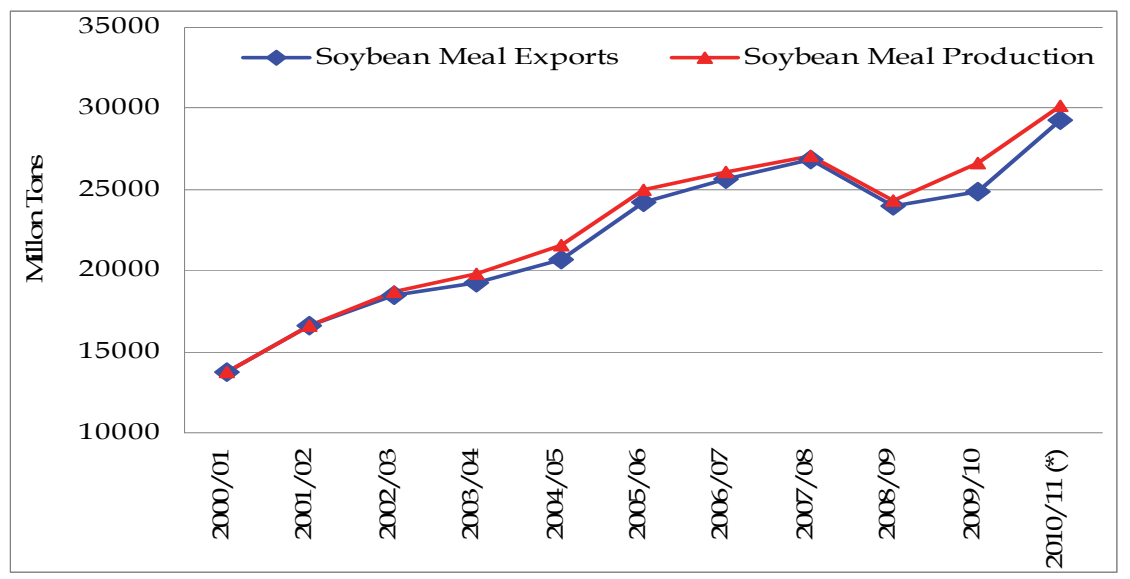

Fig. 7. Argentina. Soybean meal. Production and exports (2000/2001-2010/2011).

If the soybean meal exports by each company is examined (Table 6). The first five companies participate with $78.5 \%$ of the total national exports. It can be seen that the first four meal exporting companies are the same as the first four oil exporting companies being Cargill the first $(28.4 \%$ in oil and $23 \%$ in meal, 2008).

\begin{tabular}{||c|c|c|c||}
\hline Company & $\begin{array}{c}\text { Share of total } \\
\text { oil export (\%) }\end{array}$ & Company & $\begin{array}{c}\text { Share of total } \\
\text { oil export (\%) }\end{array}$ \\
\hline Cargill & 28,42 & Vicentin & 3,31 \\
\hline Bunge Argentina & 18,15 & Nidera Arg. & 3,12 \\
\hline Aceitera Gral. Deheza & 14,80 & Aceitera C.A. & 2,65 \\
\hline Dreyfus & 10,91 & Oleag. Moreno & 1,44 \\
\hline Mol. Río de la Plata & 10,36 & Cia. Argentina de Granos & 1,39 \\
\hline \hline
\end{tabular}

Source, CIARA (2009)

Table 6. Soybean Argentina. Exporting soybean meal companies .Participation in the total exported 2008 . 


\section{Domestic commercialization, storage and logistics and transportation services}

\subsection{Comercialization. Main characteristics}

Ninety five percent of the soybean harvest goes from farmers to country grain elevators (private or local cooperatives). The main final destiny is the crushing industry (oil and meal). The second destiny in importance are the exporters. The remaining activities have a small participation in the grain final destiny. Among these activities the animal feed producers and the grain purchase for own consumption (cattle producers) can be found.

The commercialization stages are divided according to the offerers, been primary operations when the seller of the goods is the producer; secondary operations when the goods are sold by any of the intermediary agents to exporters or to the industry, and finally, terciary operations which are those where exportation is involved.

In the primary stage, the "producers" are the ones who make up the supply : they can be land owners, tenants, contractors, pool producers, agricultural investments common funds, and the demand are usually country grian elevators, first grade cooperatives, livestock producers (poultry, pork, feed lot), exchange dealers ${ }^{31}$, industries and expoterers with vertical integration strategies.

The secondary stage is focused on country grain eleators, local cooperatives, inputs providers and exchange dealers as well as exporters, industrials and livestock producers.

Brokers and institutions like the Stock Exchange, Cereal Boards and Arbitration Chambers can also take part in any of these stages. They -boards and chambers- are Arbitration Courts in case there is any kind of controversy. They set reference prices and have grain analysis laboratories. In Argentina, there are four Cereal Boards: Buenos Aires, Córdoba, Bahía Blanca and Entre Ríos.

As regards the transaction steps, the most representative ones can be divided between those made with merchandise readily available or not. The most common payment ways when the goods delivery is effectively done can be: cash on delivery, cash with insured delivery quota, cash with uncertain delivery, cash on deposit certificates or a price to be fixed. When the goods are to be delivered in the future, the payment ways can be: advance payment, exchange (with other goods), and forward payments (with a contract).

In Argentina, there are also two exchange markets where Futures and Options contracts on soybean can be made: "Rosario Futures Exchange (Rofex)" and "Mercado Término de Buenos Aires (MATBA)" where soybean oil contracts can be found. Although the use of these instruments is growing; it is not widely spread yet, specially among the small producers. Besides, successive economic crisis and interventions in the agricultural markets have slowed down its development. It is important to point out that this alternative is use to secure prices rather than to deliver the goods. The use of these markets is around the $28 \%$ of the total average production in the last five years (2005-2009).

The operators that take part in grain commerce have been classified according to their function into 17 categories by the National Office of Agroindustrial Commerce and Control (ONCCA, 2006). The ones involved in soybean markets are: country grain eleators (2685), grain conditioners (62), industrials (58), industrial-selector (35), laboratory (25), public scales (21), Futures Market (3), consigner without facilities (2), broker (359), importer (27), exporter (356), exchange agent (665) and delivery agent (11).

${ }^{31}$ Exchange dealers receive soybean as a form of payment for goods in general and for leasing. 
Different trading channels and modalities combined with the large number of operators makes it possible to trade soybean in a very extended way. But since it's not compulsory to register the operations modality, no statistics reflect in a reliable way which the most chosen channels are. Anyway, these modalities are in general incidental and depend on the market situation.

\subsection{Storage}

The expansion of the storage capacity in Argentina was historically related to the volume and composition of the country grain production and also to the politicies officially developed in relation to the way of trading. In the last years, an expansion of the storage capacity is observed. This expansion had its origin, among other factors, in the sustained increase of grain production, which implied a growing need of places to keep this production. (Lopez, 2008)

\begin{tabular}{||c|c|c||}
\hline & Tons & $\%$ \\
\hline Grain storage companies-Cooperatives & 38.204 .066 & 53,86 \\
\hline Producer (fija) & 15.900 .000 & 22,42 \\
\hline Oil mills & 7.655 .511 & 10,79 \\
\hline Exports-Ports & 4.759 .119 & 6,71 \\
\hline Flour Mills & 2.552 .024 & 3,60 \\
\hline Animal Feed Proucers & 785.947 & 1,11 \\
\hline Rice Mills & 555.827 & 0,78 \\
\hline Conditioner & 517.450 & 0,73 \\
\hline Permanent facilities & $\mathbf{7 0 . 9 2 9 . 9 4 4}$ & $\mathbf{1 0 0}$ \\
\hline Silo bag & 30.000 .000 & \\
\hline Total & $\mathbf{1 0 0 . 9 2 9 . 9 4 4}$ & \\
\hline \hline
\end{tabular}

Table 7. Argentine Storage Capacity

Producers kept the grain in the farm (when possible) or storage them in local cooperatives and country grain elevators or in the silos found in ports or factories (Table 7). National storage capacity in 2007 was nearly of 71 million tons. It must be mentioned that there's no official information in this area so the growth rate considered was similar to the one observed in former periods. (Lopez, 2008) ${ }^{32}$

\subsubsection{The silo bag as a storage alternative}

Between 1999/2000 silo bag33 storage technique was introduced (Picture 1). It is a complementary capacity not only at a producer level but also in the case of some country grain elevators (FAO-SAGPYA, 2004). This technique consists of storaging the grains in hermetic plastic bags where the breathing process of the grain biotic components (grains, fungus, insects, etc.) consume the oxygen generating in turn carbone dioxide. This new

\footnotetext{
32 It is important to remember information about the storage capacity in Argentina is scarce and in some cases of uncertain reliability (Lopez, 2008).

${ }^{33}$ The relationship installed capacity/silo bag was $2,66 / 1,30 \%$ of total storage capacity. See Table 7 .
} 
atmosphere rich in carbone dioxide and poor in oxygen suppress, inactivate or reduce the reproduction capacity and/or fungus and insects development and also the proper grain activity which in turn makes it easier to store them (Casini, 2002).

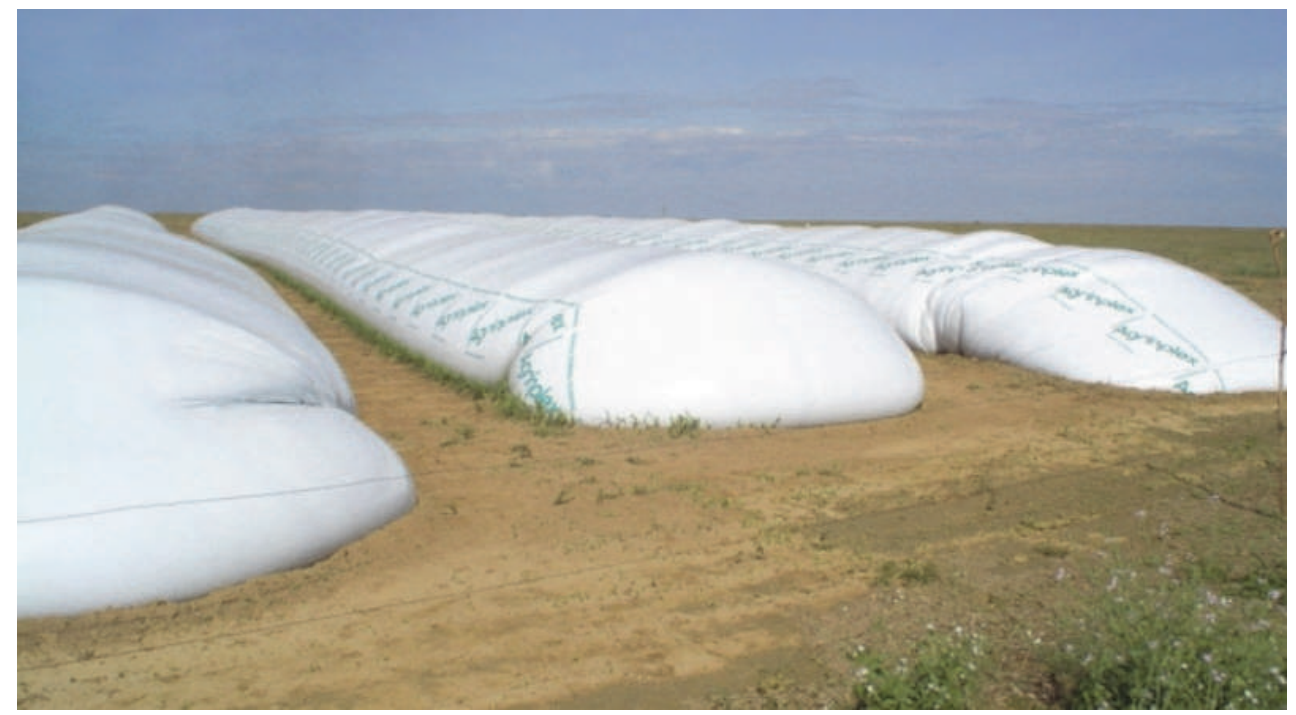

Picture 1. Silo Bag

The spread of the use of this technology introduced new possibilities (it increased the retainining grain autonomy at a low cost) -although with certain limitations ${ }^{34}$ - and also generated an additional service circuit formed by the bagging and unbagging offerers, as weel as the production of stuffing machinery (Bisang and Sztulwark, 2007). The increase observed in the use of silo bags, is an expression of a bigger storage capacity needed.

The use of this way of storing among the producers and country grain elevators allows them ${ }^{35}$ to keep grain and make deliveries, avoiding high freight costs during the harvest time. If Soybean is stored in a dry and clean way, it can be kept between 4 and 12 months in good conditions. This allows to improve income up to $15.5 \%$ (average, if sold in the month of January)(Ghida Daza , 2002).

\subsection{Logistics and transportation services}

Argentina has lower costs as regards production for most of the agricultural products where it has an important share of the global market, but it has higher costs as regards the commercialization than its most important competitors: Brazil and the United States (Dohlman et al., 2001; Tavarez 2004; Nardi and Davis, 2006). The higher commercialization costs are due to, in the case of soybean, higher transport, storage and exportation tariff (Nardi and Davis, 2006). Eighty four percent of the grain production is taken to the

\footnotetext{
${ }^{34}$ Possibility of bag breaking and subsequent loss of stored grain quality.

35 Other advantages would be: to activate the harvest when the production is stored in the same productive land and to obtain credits on the stored grain (Warrant)
} 
exporting ports by truck $36,14,5 \%$ by rail and $1,5 \%$ by barges. Grain exports are made approximately $90 \%$ by ship, $7 \%$ by truck and the rest by rail and barge.

According to data from the Stock Exchange of Rosario, the Gran Rosario area (province of $\mathrm{Sta} \mathrm{Fe}$ ) is the one with the highest growth as regards land cargo transportation in Argentina in the last decade with annual volumes of around 60 million tons of grain products; 8 million tons of these annual volumes come by rail ${ }^{37}$ and 52 millons by truck. This implies that during the year an average of 5.000 trucks per day are concentrated. This number increases during the harvest months. (Giancola et al., 2010).

Although there is a tariff difference between the truck and the rest of the means of transport (truck versus barge 3.25 to 1 , truck versus rail38 2.5 to 1 (Commercial Infrastructure Area) (SAGPYA, 2007), the strong participation of the truck for domestic freight is due to its speed and flexibility to adapt to the resources and conditioning structures. The storage centers are generally located in the productive areas or within a radius of $20 \mathrm{~km}$ and at anerage distance of $300 \mathrm{~km}$ to the industrial centers and port terminals ${ }^{39}$. The national road infrastructure has a total extension of approximately $38.000 \mathrm{~km}$.

Motor carrier: The trucking fleet is approximately 400.000 units. For cereal and oilseeds transport there maybe 5,000 special units, but there are around 60,000 general cargo units adaptable to this need. The average cargo capacity of a truck is 28 tons. The average age of these trucks is around 25 years, in an atomized system of car properties.

Railway transport: One of the limitations to its development as a mean of transportation is that more than 1,700 establishments which work as storage centers ( $83 \%$ of the total) does not have rail access (ONCCA, 2006). The present rail granted companies which are now giving cargo services are: ALL Central, ALL Mesopotamico, Ferro Expreso Pampeano, Belgrano Cargas and Nuevo Central Argentino (NCA). (Giancola et al., 2010). Each company attends a different region, and all reach the Ports of Rosario. Regarding the operating capacity for the grain transport and its derived products of all the net rails, there are nowadays nearly 6.500 wagons (40 tons in each grain wagon depending on the gauge) between solid and liquid cargo and a totalnet of approximately $28,000 \mathrm{~km}$ (SAGPYA, 2007).

Fluvial/Maritime transport: There are 40 Argentine port terminals which have the capacity to deliver grain, oil and protein meal in bulk. Eight of these are maritime and they are located in the province of Buenos Aires. The maritime terminals deliver $19 \%$ of the cargo of this kind of products. The other 24 shipment terminals are fluvial, and from them $81 \%$ of the grain, vegetable oil and protein meal is delivered.

Most of the soybean complex products are exported from the Paraná River, in the north and south of the city of Rosario, from San Martin Port to Arroyo Seco; this section covers $70 \mathrm{~km}$.

\footnotetext{
${ }^{36}$ Compared to Brazil and the United States, Argentina is one of the exporting countries which makes the biggest use of the truck due to the average distance between the primary productive centers and the industrial processing.

37 With the use of the motor carrier, the rail transportation use was reduced since the former is more versatile and it does not have a fixed minimum volume or a fixed route.

${ }^{38}$ These differences are kept although the rail tariff has increased due to the raise in the petroleum cost since 2002.

39 With the shift of the agricultural frontier to the North East and North West of Argentina where distances to the port of Rosario are more than $350-400 \mathrm{~km}$ the transport cost incidence due to the rail use would decrease making those regions more competitive .
} 
These river port terminals deliver $76 \%$ of the cereal, oilseeds protein meal and vegetable oil exports and the rest of the river port terminals deliver $4 \%$ of global cargo.

The grain solid by products storage volume in the Paraná Hydroway ports grew from 1.5 million tons to almost 8 million. The cargo boats rhythm, in turn, grew from 23 million tons per hour to 54 million tons between 1990 and 2007. This operative capacity growth also allowed a growth of the Up-River exports from 13.5 million tons to 54 million tons as regards grains and pellets, at no extra costs of storage or delays of the cargo boats stays (SAGPYA, 2007).

\section{Future context for the Argentine soybean chain}

At an international level, it is considered that soybean prices will keep growing. This conclusion is drawn from the soybean world market indicators (supply, demand, stock, consumption) and ratified by the wider expansion of the world demand regarding the supply. If finantial speculation is added, the positive trend towards rising prices gets stronger. This conclusion is drawn after an analysis of the following factors (USDA, 2010):

- Grain production growth motivated specially by the larger demand of developing countries (DC) (consumption growth of food and forage for animals due to the per capita income growth and diet changes).

- Global growth more accelerated in DC (city planning processes and middle class expansion).

- Oil consumption growth in China (34\% imports growth during 2011 whereas in India there will be $21 \%$ imports drop).

- $\quad$ Bio-fuel demand growth in the developing countries and in the DC.

It is expected that the good crop perspectives determine that the area planted remains and/ or increases, depending onthe economic perspectives of other summer crops, specially corn.

In Argentina, it is expected that in the short-medium term the discontinuous purchase of soybean oil will continue to be done by China due to the commercial barriers implemented by the government of Argentina and China, except that an agreement between both countries is reached. This has caused that the oil exports go to other countries which buy this oil at a lower price ${ }^{40}$. So, the Argentine oil industry -which is one of the most efficient in the world- gets lower prices and, furthermore, works under its milling capacity.

At a national level and at the primary production link, there have been and there are conflicts between the soybean protagonists (soybean producers, agrochemical companies, commercial companies; etc) and different groups that question this "soybean production system", in Argentina ${ }^{41}$. Among those who question this "soybean production system", it can be mention the small and medium farmers, aborigine communities and countryside workers expelled by the spreading of soybean sowing. At the same time large company

\footnotetext{
40 The argentine soybean oil quotation suffered a discount with respect to other markets like the Brazilian one of up to U\$D 75.5 per ton (average of U\$D 50 per ton). These figures affect the almost 6 million soybean oil tons that Argentina would export in the current season

${ }^{41}$ In the mid 70s and with the use of new varieties, the sowing of two annual crops (doble -sowing) was possible. These crops are combined with the wheat production (short cycle wheat) and therefore the double crop wheat-soybean appears. This process originated a larger agricultural process (cattle is left aside) but soybean also leaves aside crops like corn and sorghum
} 
groups $^{42}$ are consolidated and thus finance great scale farming and livestock directed by contractors who rent the fields.

Also among those that question the advance of soybean production there are some professionals and environmentalists who show the farming effects as regards the distribution of the productive and environmental resources. Some of these concerns are:

- Growing loss of food sovereignty due to the soybean growing substitution.

- The soybean monoculture generates among other consequences: productive variability fall, low genetic variability, sanitary risks (new plagues, resistence to plagues and diseases).

- Soybean takes the soil nutrients, wich demands crop rotation, and in certain soils its sowing is not advaisable. Each year, soybean takes one million tons of nytrogen and more than 227,000 tons of phosphorus. Likewise, the organic material balance is negative since the mineralized carbone cannot be compensated by the one of the soybean remains.

- The soybean monoculture produce an intense soil degradation in the long run, with a losses of between 19 and 30 soil tons per hectare depending on management, soil sloping and weather .

- The no-till cropping implies strong applications of agrochemicals. Massive use of glyphosate (160 million liters in 2004/2005) and other agrochemicals (between 20 and 25 million liters of 2-4-D (herbicide), and nearly six million liters of atrazine and 6 million liters of endosulfan; these last two, insecticides.

- The product in wich glyphosate is the active principle (Round up) has a series of coadjutant that increase its toxicity considerably, specially the polioxietil amina (surfactant), whose acute toxicity is 3 to 5 times higher than the one of the glyphosate.

- The advance of the soybean over the native forests (massive deforestation and loss of biodiversity). Between 1998 and 2002, more than 2 million hectares of native forest were deforestated 43 .

Thus, there is a scenery of progressive conflict, where soybean excellent prices are signals for producers to continue with the expansion of soybean, and for other social groups (small farmers, environmentalists, professionals, etc.) to press because of the environmental and social consequences of this expansion.

\section{Conclusions}

Beyond the positive aspects related to the primary production (more security than other crops specially due to weather conditions, considerable finantial rentability, etc) the soybean growth has had positive effectsin Argentina, like the strong investments in new technologies (no-till cropping) biotechnology (transgenic soybean, fertilizers and herbicides), intensive use of agricultural machinery, storage (silo bags), logistics (private ports), net organitation (of services and financing), industrial machinery development, biofuel and agro food development the significant income of currency for the economy, without forgetting to mention the levying of export duties.

42 "Los Grobo" Group claims that they grow 150 thousand hectares in Argentina and attemps to control 750 thousand hectares in all the Southern Cone (Paraguay, Brazil and Uruguay).

${ }^{43}$ Beginning of the century: 100 million hectares in forests, at the end of XX century: 33 million hectares 
Without minimazing the positive effects or the conflicts brought about by the soybean expansion in Argentina, this crop has also generated a strong dependence 44 -a scarce commercial diversification -since only one product (soybean bean and its derived products) represent $25 \%$ of the total exported by Argentina (14.041 million dollars) (INDEC, 2009). This exporting dependence gets worse because the diary products, fruit, vegetable oil and meat are considered "Low Technological Level", whereas milling products are labeled as "Middle-Low Technological Level" (the technological content is based on the expenses in I+D) (CEP, 2007). At a Gross Product Level, the soybean chain (2009) represents $5.4 \%$ of the national added value $(0.77 \%$ in the two-year period $73 / 74)$.

The strong soybean dependence is also seen in indicators like the soybean crop area and the soybean oil and meal production. At a primary level, soybean covers $54 \%$ of the cultivated area (more than 18 million has) over the total implanted (28 million has). For the oil and meal production numbers are more significant: the soybean oil production in Argentina participates in the $79 \%$ of all oil manufactured and in the $93 \%$ of all the meal produce.

This shows that the oil argentine industry depends basically on soybean. It must be pointed out that the oil industry milling capacity is 57 million tons; $37-38$ million of which were used in the year 2010 .

This idle capacity cannot be covered with the imports since the current imports regulations mekes it too costly. Thus, the industry competitiveness will be limited to the crops primary production and to the fundamental characteristics of domestic low consumption of byproducts which allow strong exportable balance. This last one, shortened with the current domestic soybean use for biodiesel production.

Finally, the National State role must be examined and also the implemented policies in relation to the agricultural production. During 2011, due to higher expenses ${ }^{45}$, the National State do not show any sign to eliminate ${ }^{46}$ the exporting duties ${ }^{47}$, especially the ones which belong to the soybean complex. These obligations represent (2010) 8.7\% of the total taxes. This shows the importance of the exports duties and the dependence of these assets for the expense policies. The exporting duties were 7,400 million dollars; of which 6300 million dollars were collected by the soybean complex (2011).

\section{References}

Ablin, E., Paz, S. (2003). El mercado mundial de la soja, la República Argentina y los organismos genéticamente modificados, In: Las Negociaciones comerciales multilaterales de la Ronda Doha. Desafios para la Argentina. Centro de Economía Internacional. (7-54). Instituto del Servicio Exterior de la Nación. Ministerio de Relaciones Exteriores de Argentina. Buenos Aires. Argentina

\footnotetext{
${ }^{44}$ The risks of non-tariff imposition barriers for genetically modified soybean must be considered.

${ }^{45}$ During 2009 and 2010 the State Budget result was negative (income lower than total expenses).

${ }^{46}$ In the National Legislature (Commission) a project to modify the exporting duties obligations is being debated.

${ }^{47}$ In the year 2002 export reimbursements were implemented: the soybean oil 1.6for the raw oil in bulk; $5 \%$ for refined oil in containers of $5 \mathrm{~kg}$ and $0,7 \%$ for the raw oil. All the above mentioned refunds were left aside $(0 \%)$ since November, 2005. The raw oil but the exported volumes of refined oil represent only $3 \%$ of all the soybean oils.
} 
ACSOJA. (2009). Importancia económica de la soja. 15/08/2010. Available from: http:/ / www.acsoja.org.ar/ampliarII.asp?intIdSection=88\&intIdContenido=217.año

Bisang, R. (2003). Apertura Económica, innovación y estructura productiva: la aplicación de biotecnología en la producción agrícola pampeana argentina. In: Desarrollo Económico. Vol. 43 No 171. (413-442). Buenos Aires. ISSN 0046-001X

Bisang, R., Sztulwark, S. (2007). Tramas productivas de alta tecnología y ocupación. El caso de la soja transgénica en la Argentina. In: Estructura productiva y empleo. Un enfoque transversal. Primera edición. (181-224). ISBN 978-84-36571-68-6 (web, pdf)

Brieva, S. (2006). Dinámica socio-técnica de la producción agrícola en países periféricos: configuración y reconfiguración tecnológica en la producción de semillas de trigo y soja en Argentina, desde 1970 a la actualidad. Tesis doctoral. Facultad Latinoamericana de Ciencias Sociales (FLACSO). (pp.292)

Cámara Industrial de Aceites de la Republica Argentina (CIARA). (2011). Estadísticas de soja. 10/02/2011. Available from: http:/ / www.ciaracec.com.ar/estadísticas

Casini, C. (2002). Guía para almacenar grano en bolsas plásticas. In: Información técnica Proyecto eficiencia de cosecha y postcosecha de grano. (1-4). Instituto Nacional de Tecnología Agropecuaria (INTA) Manfredi, Córdoba.

Cámara Argentina de Biocombustibles (CARBIO). (2011). Estadísticas de biocombustibles. 13/02/2011. Available from: www.carbio.com.ar/es/?com=bio_estadísticas

Centro de Estudios para la Producción (CEP). 2007. “Contenido tecnológico de las exportaciones argentinas 1996-2007. Tendencias de upgrading intersectorial". 1/08/2010. Available from:

www.cep.gov.ar/descargas_new/contenido_tecnológico_exportaciones_ 19962207.pdf

Civitaresi, H., Granato, M. (2003). El complejo oleaginoso argentino: algunos factores determinantes de su desempeño exportador. Revista Argentina de Economía Agraria. Vol. VI, 1, (Otoño 2003), pp. 37-47), ISSN 0327-3318

Dohlman, E., R. Schnepf., Bolling, C. (2001). Agriculture in Brazil and Argentina: Developments and Prospects for Major Field Crops. In: Washington, DC: US Department of Agriculture, Economic Research Service. Agriculture and Trade Report. WRS-0-1-3. 5/02/2011. Available

http://www.ers.usda.gov/publications/wrs013/wrs013g.pdf.

EUMERCOPOL (2007). EU-Mercosur. Agrifood Systems Comparison. In: Proyecto. Documento de Trabajo Work Package 4. Buenos Aires.

Facultad de Agronomía, Universidad de Buenos Aires (FAUBA). (2004). Informe Final LART/FAUBA. Patrones espaciales y temporales de la expansión de soja en Argentina. Universidad Nacional de Buenos Aires. Buenos Aires, Argentina.

FAO-SAGPYA. (2004). Análisis de las cadenas de maíz y soja en Argentina, con vistas a exportación de mercaderías OVM y no OVM en el marco del art. 18.2 a) del Protocolo de Cartagena sobre seguridad de la biotecnología. Proyecto FAO-SAGPYA. TCA/ARG 2903. Documento $\mathrm{N}^{\circ}$ 2. Dirección Nacional de Mercados Agroalimentarios. Organización de Naciones Unidas para la Agricultura y la Alimentación. Buenos Aires, Argentina.

Fundación Producir Conservando. Capacidad de almacenamiento. (2010). Available from: http:/www.producirconservando.org.ar 
Giancola, S., Salvador, L., Covacevich, M., Iturrioz, G. (2010). Análisis de la cadena de soja en la Argentina. En: Estudios Socioeconómicos de los Sistemas Agroalimentarios y Agroindustriales $N^{o}$ 3. INTA, Buenos Aires. ISSN 1852-4605.

Ghida Daza, C. (2002). Alternativas para el almacenaje. Silo bolsa de grano seco. In: Maíz, actualización 2002. Información para extensionistas. INTA Marcos Juárez.

Gutman, G., Lavarello, P. (2003). La trama de oleaginosas en Argentina. In: Estudios sobre el sector Agroalimentario. Estudio 1.EG.33.7 Componente B: Redes Agroalimentarias, Tramas B-3. Bisang R., y G. Gutman. CEPAL-ONU, Buenos Aires.

Instituto Nacional de Estadística y Censos (INDEC). (2009). Estadísticas macroeconómicas. 20/02/2011. Available from: http://www.indec.mecon.gov.ar

Instituto Nacional de Tecnología Agropecuaria (INTA). Consejo del Centro Regional Santa Fe., (2009). Documento institucional. El avance de la soja en la Argentina y la sostenibilidad de los sistemas agrícolas. In: INTA Centro Regional Santa Fe. Febrero 2011. http:/www.inta.gov.ar/reconquista/crsantafe/docsoja.htm

Lopez, G., (2008). Vamos al grano?. El Rol del Estado en el comercio granario argentino (primera edición). Editorial Cúspide. ISBN 9789870588023. (288 pp).

Nardi, M., Davis, T., (2006). Supply chain management in Argentina and Brazil and the Effect on World Agricultural Competitiveness. Presentation given to trading companies. Buenos Aires, March 2006. 92 pp.

Obschatko, E., (1997). Articulación productiva a partir de los recursos naturales. El caso del complejo oleaginoso argentino (Primera edición). Documento de trabajo $\mathrm{N}^{\mathrm{o}} 74$. CEPAL, Buenos Aires. UNDP Project RLA 88/039. Buenos Aires, Argentina.

Oficina Nacional de Control Comercial Agropecuario (ONCCA). 2006. Existencia física de granos al 31 de Diciembre 2006. 6/02/2011. Available from: http://www.onnca.gov.ar

Quaim, M., Traxler, G. (2002). Roundup Ready Soybeans in Argentina: Farm Level, Environmental and Welfare Effects. Proceedings of Conference ICABR on Agricultural Biotechnologies: New Avenues for Production, Consumption and Technology Transfer. Ravello, Italia. Julio 2002.

SAGPyA (2007). Informe de fletes y preliminar de transporte de granos. 12/02/2011. Available from: http://www.minagri.gob.ar/publicaciones.php

Schavarzer, J., Tavosnanska, A. (2007). El complejo sojero argentino. Evolución y perspectivas. Centro de Estudios y Perspectivas de la Argentina (CESPA). Universidad de Buenos Aires. Facultad de Ciencias Económicas. Documento de trabajo $N^{\circ} 10$. Buenos Aires.

Tavarez, C. (2004). Factores críticos a Competitividade da Soja no Parana e no Mato Grosso. Companhia Nacional de Abastecimiento. Brasilia. 9 pp.

Trigo, E., Cap, E. (2006). Diez años de cultivos genéticamente modificados en la Agricultura Argentina. Consejo Argentino para la Información y el Desarrollo de la Biotecnología- ARGENBIO, Buenos Aires, Argentina. 53 pp

United State Department of Agriculture (USDA). (2010). USDA data base: commodities and trade. In: USDA Foreign Agricultural Service. 29/01/2011. Available from: www.fas.usda.gov/commodities.asp and /trade.asp 


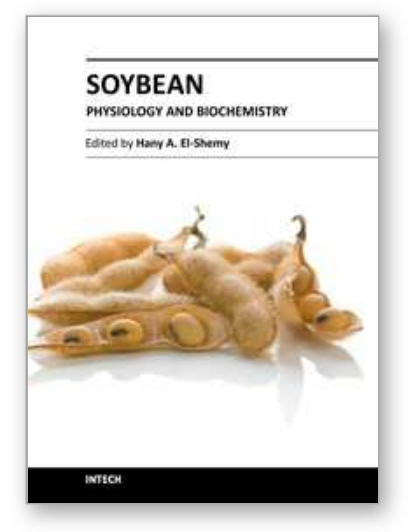

\author{
Soybean Physiology and Biochemistry \\ Edited by Prof. Hany El-Shemy
}

ISBN 978-953-307-534-1

Hard cover, 488 pages

Publisher InTech

Published online 02, November, 2011

Published in print edition November, 2011

Worldwide, soybean seed proteins represent a major source of amino acids for human and animal nutrition. Soybean seeds are an important and economical source of protein in the diet of many developed and developing countries. Soy is a complete protein and soyfoods are rich in vitamins and minerals. Soybean protein provides all the essential amino acids in the amounts needed for human health. Recent research suggests that soy may also lower risk of prostate, colon and breast cancers as well as osteoporosis and other bone health problems and alleviate hot flashes associated with menopause. This volume is expected to be useful for student, researchers and public who are interested in soybean.

\title{
How to reference
}

In order to correctly reference this scholarly work, feel free to copy and paste the following:

S. Calvo, M. L. Salvador, S. Giancola, G. Iturrioz, M. Covacevich and D. Iglesias (2011). Causes and Consequences of the Expansion of Soybean in Argentina, Soybean Physiology and Biochemistry, Prof. Hany El-Shemy (Ed.), ISBN: 978-953-307-534-1, InTech, Available from:

http://www.intechopen.com/books/soybean-physiology-and-biochemistry/causes-and-consequences-of-theexpansion-of-soybean-in-argentina

\section{INTECH}

open science | open minds

\section{InTech Europe}

University Campus STeP Ri

Slavka Krautzeka 83/A

51000 Rijeka, Croatia

Phone: +385 (51) 770447

Fax: +385 (51) 686166

www.intechopen.com

\section{InTech China}

Unit 405, Office Block, Hotel Equatorial Shanghai

No.65, Yan An Road (West), Shanghai, 200040, China

中国上海市延安西路65号上海国际贵都大饭店办公楼405单元

Phone: +86-21-62489820

Fax: $+86-21-62489821$ 
(C) 2011 The Author(s). Licensee IntechOpen. This is an open access article distributed under the terms of the Creative Commons Attribution 3.0 License, which permits unrestricted use, distribution, and reproduction in any medium, provided the original work is properly cited. 